\title{
Impact of Land Use Land Cover Changes on Runoff Processes of Chalakudy Basin
}

\author{
Nchumbeni M. Odyuo* and K. P. Rema \\ Department of Irrigation and Drainage Engineering, Kelappaji college of Agricultural \\ Engineering and Technology (KAU), Malappuram, Kerala, India \\ *Corresponding author
}

\begin{tabular}{l} 
Ke y w o r d s \\
Chalakudy basin, \\
LULC changes, \\
Landsat, \\
Unsupervised \\
classification and \\
ERDAS \\
\hline Article Info \\
\hline $\begin{array}{l}\text { Accepted: } \\
\text { 24 October } 2020 \\
\text { Available Online: } \\
\text { 10 November } 2020\end{array}$ \\
\hline
\end{tabular}

A B S T R A C T

Fast development of urbanization alongside other expanding anthropogenic factors have been distinguished as significant reasons of land use changes and land transformations, which eventually presents several devastations like floods, dry season, water contamination and soil debasement. Dissecting the spatial and temporal changes in LULC of basin gives significant understanding to these issues and is one of the analytic strategies to comprehend the issues continuing in a basin. The state of Kerala in particular is notable for significant level of development as far as socio-monetary components, education, human services and so forth are considered. The broad financial changes have prompted expanded pace of framework, building development and abundant scene changes in the most recent decade. The Chalakudy river basin which is in Kerala has been the wellspring of floods since the last recent years and has made a tonne of harms to the basin. For the present study we have compared and analyzed the LULC changes of three different years i.e., 1997, 2007 and 2017. The after effects of the satellite map investigation have demonstrated how urbanization being one of the most significant reasons for LULC changes in the Chalakudy basin has altered the overall basin ecology. It was observed that the vegetation area decreased consequently from $886.21 \mathrm{~km}^{2}$ to $803.09 \mathrm{~km}^{2}$ while the urban area was found to increase from $31.74 \mathrm{~km}^{2}$ to $41.93 \mathrm{~km}^{2}$ (1997-2017). From the net area gain-loss calculation the highest area loss was found to be of vegetation for both the decades with an area of $223.84 \mathrm{~km}^{2}$ and $178.59 \mathrm{~km}^{2}$ respectively.

\section{Introduction}

Land is turning into a rare asset because of populace development and industrialization. Because of advancement in lifestyle of the people and setting up of various industries there is quick change in LULC and in urban regions specifically. The sporadic development in urban spread has caused an incredible effect on the land. The terms land use land cover is regularly utilized conversely, yet each term has its own interesting significance. Land cover is the physical material at the outside of the earth. Land use is the portrayal of how individuals use the land for the financial action. Land use and land cover changes may have four significant direct impacts on the hydrological 
cycle and water quality: they can cause floods, dry seasons and changes in waterway, groundwater systems and they can even influence water quality.

Land use and land cover (LULC) of the earth is changing drastically as a result of human exercises and cataclysmic events. Changes of LULC design particularly in developed zones have prompted an extension of impenetrable land which has altogether influenced the surface overflow conduct in the urban domain. Expanded pace of urbanization alongside other human intercession factors have been referred to as significant difficulties encountered by streams, which in turn changes the overall basin ecology and ends up in characteristic ruins like floods and dry seasons. Deforestation and change of waterlogged wetlands into developed zones influence the qualities of the basin, common water stream systems and the conspicuous result is flood. Most definitely the spatiotemporal changes in land use have direct impact on its hydrological domain. Flooding is unpredictable and this hazard is frequently being experienced. Overseeing to diminish the flood peril, a basic job is to keep up the balance between natural environment, physical and social condition of various social orders and their financial improvement. Dealing with such hazard is essential for lessening harm and adjusting the impacts of environmental change to land use change. Therefore, the evaluation to decrease the flood dangers ought not to be overlooked. Land use-land cover changes examination gives data to organizers and helps the users on what ought to be done to have sensible and adjusted improvement that will be economical and eco-accommodating.

Satellite remote sensing information is typically the most exact and cutting-edge map accessible for studying the LULC which prompts locating the progress. Particularly with quickly developing towns and urban communities in India it is the best technique that can catch up the urban development/spread. Therefore, remote sensing information along with Geographical Information System (GIS) gives productive techniques to investigate LULC changes.

Kerala in particular is notable for significant level of development as far as sociomonetary components, education, human services and so forth are concerned. The broad financial changes have prompted expanded pace of framework, building development and abundant scene changes in the most recent decades. The Chalakudy basin which is in Kerala, has been the wellspring of numerous floods since the last recent years and has made a tonnes of harm to various pieces of the ranch, gardens, domesticated animals, neighbourhoods, and frameworks including streets, spans etc. The basin attributes of Chalakudy basin has encountered varieties of critical situations such as repeated flood occurrence and dry seasons which has also become an overwhelming element of this stream, as the basin is considered to be the life saver of the area. The changes in the land use example of Chalakudy stream basin uncovered 'negative changes' right now disturbing the overall basin ecology which is presently being experienced in the form of natural disasters. The recorded outcomes from the recent floods uncovered that the greater part of the flood influenced territories are missing hydrological studies which clarifies an appraisal study of this region facing flood hazard frequently. Hence, this study ought to tackle such problem that had occurred in Chalakudy basin during the most recent two decades through the land use/land cover (LULC) changes analysis which was prepared for three different years i.e., 1997, 2007 and 2017 by applying the remote sensing techniques. 


\section{Study area}

Chalakudy river is the fifth longest stream in Kerala which lies between $10^{\circ} 05^{\prime}$ to $10^{\circ} 35^{\prime}$ North latitude and $76^{0} 15^{\prime}$ to $76^{0} 55^{\prime}$ East longitude and passes through Palakkad, Thrissur and Ernakulam districts. The basin is limited by Chittur and Alathur Taluks of Palakkad area and Mukundapuram Taluk of Thrissur district in the North, Alwaye, Kunnathunad and Paravur Taluks of Ernakulam region in the South, Kodungallur Taluk of Thrissur region in the West and Tamil Nadu in the East. Chalakudy river basin begins from the Anamalai slopes of the Western Ghat mountain ranges and courses through the northern part of Periyar stream. The basin gets a normal precipitation of around $3,000 \mathrm{~mm}$. The Chalakudy basin is partitioned into 57 sub watersheds and 140 small scale watersheds. The shape of Chalakudy basin is roughly triangular with its base along the east, having a length-width proportion of 3:1. Chalakudy basin is surrounded by the meeting of four significant tributaries specifically Sholayar, Parambikulam, Kuriarkutty and Karapara. The stream has a length of around $130 \mathrm{~km}$ and a catchment region of around $1,704 \mathrm{~km}^{2}$. Out of the absolute catchment region around 300 $\mathrm{km}^{2}$ lies in Tamil Nadu and the rest $1404 \mathrm{~km}^{2}$ is within Kerala region.

\section{Materials and Methods}

Over the past years remote sensing detecting techniques and Geographic Information System (GIS) have been applied for the preparation of several LULC maps to evaluate its impact on runoff and the occurrence of flood globally. This study attempts to evaluate the LULC changes that have taken place in Chalakudy river basin between the years 1997-2017 by using remote sensing based digital satellite images. Analysis of land use/land cover changes in Chalakudy basin was done for three years i.e., 1997, 2007 and
2017. Both the satellite image and DEM were collected from the USGS earth explorer. The satellite images of Land sat 7 thematic mapper for the years 1997, 2007 and 2017 with a $30 \mathrm{~m}$ resolution was taken to prepare the LULC map (Fig. 1). The images for the months of February and April were selected for 1997 and 2017 to make sure that the image is cloud free. The satellite image for 2007 was downloaded for the month of December as there was no clear image from the month of February to April. Delineation of the basin was done using the extension tool HEC-GeoHMS and the LULC map for each year was prepared using ERDAS Imagine, by unsupervised classification. The three LULC maps were prepared by dividing the basin into 7 classes viz., water body, vegetation, urban area, barren land, tea, paddy and palm. After preparing the LULC map, the area calculation, percentage area coverage and decadal percentage change of each class was calculated and the annual rate change of area was also calculated for two different decades i.e., 1997-2007 and 2007-2017. The procedure developed by Puyravad et al., (2003) Teferi et al., (2013) and Batar et al., (2017) was used for calculating the annual rate change. The formula used is given below:

$$
\left(\frac{1}{T_{2}-T_{1}}\right) * \ln \left(\frac{A_{2}}{A_{1}}\right) \quad \mathrm{r}=
$$

Where, ' $r$ ' is the annual rate change of area (\%)

$A_{1}$ and $A_{2}$ are the areas of the classes $\left(\mathrm{km}^{2}\right)$ at time 1 and time 2

$\left(T_{2}-T_{1}\right)$ is the time interval (in years) between the two periods

A correlation analysis between the average rainfall and the average flow was done for two different decades and the results were depicted in a graphical format. The first decade of correlation analysis was done from 
1997-2007 followed by 2007-2017. For analyzing the change of different LULC classes, a transition change matrix was prepared as well for 1997-2007 and 20072017. The matrix was prepared with the help of Arc GIS and MS excel worksheet. The significant part of transition change analysis is to distinguish and consequently highlight the land use classes where the changes have occurred i.e., a specific class that has transformed into another class over some undefined time frame. The general format for transition change matrix is shown in table 1. The diagonal bold letters shows the amount of area that remains constant from time $\mathrm{T}_{1} \mathrm{t} \mathrm{o}$ time $\mathrm{T}_{2}$. The total gain and loss for each class was calculated from 1997-2007 and 20072017 , the results obtained were then finally plotted in a graph.

\section{Results and Discussion}

Land use changes in the Chalakudy basin were mapped for the years 1997, 2007 and 2017 and the information collected was predominantly based on the cloud free satellite image and ground truthing. The land use map relating to the years 1997, 2007 and 2017 are given in figures 2, 3 and 4 . In the present study we have compared the classified map picture for various LULC classes over the most recent two decades and specific perceptions that are disturbing were observed. The correlation among various land use and land cover indicated either a reduction or increment in the areas.

Area coverage of $27.84 \mathrm{~km}^{2}, 40.10 \mathrm{~km}^{2}$ and $29.32 \mathrm{~km}^{2}$ of urban area was noticed and the highest area coverage found was for the vegetation class which are $886.21 \mathrm{~km}^{2}$ to $833.68 \mathrm{~km}^{2}$ and $803.09 \mathrm{~km}^{2}$ respectively for the years 1997, 2007 and 2017 (Table 2). The comparison of results for various decades revealed that the vegetation zone, barren land and tea plantation showed reduction of area by $4.12 \%, 1.53 \%$ and $0.91 \%$ respectively from 1997-2007. An increase of water body, palm, paddy area and urban area by $0.97 \%$, $0.95 \%, 4.27 \%$ and $0.39 \%$ was also found after comparing the LULC maps of 1997 and 2007 (Table 4). A lessening in the water body class by $0.85 \%$ and abatement in the territory of vegetated area and tea by $2.4 \%$ and $0.64 \%$ respectively were further observed in the subsequent decade. Expansion in the territory of barren land, palm, paddy and urban area by $2.73 \%, 0.51 \%, 0.23 \%$ and $0.41 \%$ was noticed. These changes were noticed after evaluating the LULC changes that took place between 2007 and 2017 (Table 4). The reduction in the vegetation area might be a result of populace increment. The highest decrease in percentage area was found to be for vegetation class which was found to decrease consistently in between the two decades from $69.53 \%$ to $65.41 \%$ and $63.01 \%$ respectively (Table 3 ). Examination of LULC maps of 1997, 2007 and 2017 (Fig. 2, 3 and 4) revealed that the basin right now shows a fluctuating pattern for each decade with respect to different classes. Figures 2, 3 and 4 demonstrate the general changes over the time span examined.

The annual change rate of LULC classes for 1997-2007 (Table 5) was found to be the highest for paddy with $9.15 \%$ and least for vegetation with $-0.61 \%$ while for $2007-2017$ the highest declination of annual rate change was for the water body (-3.13\%) and the highest increment was for barren land (2.16\%). From 1997-2017, there was a drastic percentage change for paddy and palm with $18.93 \%$ and $9.43 \%$. The above outcomes affirm critical changes in the land use of the study area.

Relationship between the average annual rainfall and average annual stream flow for the years 1997-2007 and 2007-2017 is shown in figures 5 and fig 6. Fig. 5 shows highest average rainfall and average flow for the year 2007 and the least for the year 2000. The obvious reason behind the increment of flow 
in the year 2007 might be because of the reduction in forest area and an increment in urban zone. In view of advancement and urbanization, the infiltration capacity of the soil decreased which led to percentage increment in water body as well. For the following next decade i.e. 2017 a further declination in the water body was seen, the conceivable explanation might be the diminishing rainfall towards the decade's end and in light of which a declination in the average flow was seen towards the end of decades. Consequently, it is inferred that the increase in peak flow and the diminishing stream flow are the after effects of land use land cover changes.
An $R^{2}$ value of 0.79 (fig. 7) was obtained for the linear regression analysis plotted between the average rainfall and average flow for the years 1997-2007 while an $\mathrm{R}^{2}$ value of 0.86 (fig. 8) was obtained for the years 2007-2017. From the $\mathrm{R}^{2}$ value obtained for the two decades, it shows that the flow of the basin is dependent on the rainfall and is also influenced by other factors like the changes in the LULC over a stretch of time.

The transition change matrix obtained for the years 1997-2007 and 2007-2017 are shown in tables 6 and 7 respectively while the GainLoss area $\left(\mathrm{km}^{2}\right)$ for each LULC class and the net Gain-Loss area $\left(\mathrm{km}^{2}\right)$ for each LULC class is shown in table 8 and 9.

Table.1 General format for LULC change transition change matrix

\begin{tabular}{|c|c|c|c|c|c|c|c|c|c|}
\hline LLC & LUL1 & LUC2 & LLC3 & ULC4 & LUC5 & LUL6 & LLC7 & $\begin{array}{l}\text { TOTAL time } \\
T_{1}\end{array}$ & LOSS \\
\hline LUL1 & $\mathbf{A}_{11}$ & $A_{1}$ & $\mathrm{~A}_{\mathrm{B}}$ & $\mathrm{A}_{H}$ & $\mathrm{~A}_{15}$ & $\mathrm{~A}_{16}$ & $\mathrm{~A}_{17}$ & $\mathrm{~A}_{\mathrm{H}}$ & $\mathrm{A}-\mathrm{A}_{11}$ \\
\hline LUC2 & $\mathrm{A}_{21}$ & $A_{2}$ & $\mathrm{~A}_{23}$ & $\mathrm{~A}_{24}$ & $\mathrm{~A}_{25}$ & $\mathrm{~A}_{26}$ & $\mathrm{~A}_{2}$ & $\mathrm{~A}_{2+}$ & $\mathrm{A}_{2+}-\mathrm{A}_{22}$ \\
\hline LUC3 & $\mathrm{A}_{31}$ & $\mathrm{~A}_{32}$ & $\mathbf{A}_{\mathfrak{B}}$ & $\mathrm{A}_{34}$ & $\mathrm{~A}_{35}$ & $\mathrm{~A}_{30}$ & $\mathrm{~A}_{37}$ & $\mathrm{~A}_{3+}$ & $\mathrm{A}_{3+}-\mathrm{A}$ \\
\hline LUL4 & $\mathrm{A}_{41}$ & $\mathrm{~A}_{4}$ & $\mathrm{~A}_{4}$ & $\mathrm{~A}_{4}$ & $\mathrm{~A}_{45}$ & $\mathrm{~A}_{46}$ & $\mathrm{~A}_{4}$ & $\mathrm{~A}_{4}$ & $\mathrm{~A}_{4}-\mathrm{A}_{4}$ \\
\hline ULC5 & $\mathrm{A}_{51}$ & $\mathrm{~A}_{2}$ & $\mathrm{~A}_{53}$ & $\mathrm{~A}_{54}$ & $\mathbf{A}_{\mathbf{5}}$ & $\mathrm{A}_{56}$ & $\mathrm{~A}_{5}$ & $\mathrm{~A}_{5+}$ & $\mathrm{A}_{5+}-\mathrm{A}_{5}$ \\
\hline LLC6 & $\mathrm{A}_{6}$ & $\mathrm{~A}_{2}$ & $\mathrm{~A}_{6}$ & $\mathrm{~A}_{64}$ & $\mathrm{~A}_{6}$ & A $_{60}$ & $\mathrm{~A}_{6}$ & $\mathrm{~A}_{6+}$ & $\mathrm{A}_{6+}-\mathrm{A}$ \\
\hline LLC7 & $\mathrm{A}_{71}$ & $\mathrm{~A}_{72}$ & $\mathrm{~A}_{\mathcal{B}}$ & $\mathrm{A}_{74}$ & $\mathrm{~A}_{\bar{B}}$ & $\mathrm{~A}_{76}$ & $\mathbf{A}_{\pi}$ & $\mathrm{A}_{7+}$ & $\mathrm{A}-\mathrm{A}$ \\
\hline TOTALtime $\mathbf{T}_{2}$ & $\mathrm{~A}_{+1}$ & $\mathrm{~A}_{+2}$ & $\mathrm{~A}_{+3}$ & $\mathrm{~A}_{+4}$ & $\mathrm{~A}_{+5}$ & $\mathrm{~A}_{+6}$ & $\mathrm{~A}_{+7}^{+}$ & 1 & \\
\hline GAIN & $\mathrm{A}-\mathrm{A}$ & $\mathrm{A}-\mathrm{A}$ & $\mathrm{A}-\mathrm{A}$ & $\mathrm{A}-\mathrm{A}_{4}$ & $\mathrm{~A}-\mathrm{A}$ & A $-\mathrm{A}$ & $\mathrm{A}-\mathrm{A}$ & & \\
\hline
\end{tabular}

Table.2 Areal extent of various LULC classes during the period 1997- 2017

\begin{tabular}{|c|c|c|c|}
\hline Year & $\mathbf{1 9 9 7}$ & $\mathbf{2 0 0 7}$ & $\mathbf{2 0 1 7}$ \\
\hline LULC category & Area $\left.\mathbf{( k m}^{\mathbf{2}}\right)$ & Area $\left.\mathbf{( k m}^{\mathbf{2}}\right)$ & Area $\left.\mathbf{( k m}^{\mathbf{2}}\right)$ \\
\hline Waterbody & 27.84 & 40.10 & 29.32 \\
\hline Vegetation & 886.21 & 833.68 & 803.09 \\
\hline Barren land & 163.91 & 144.37 & 179.16 \\
\hline Palm & 30.88 & 42.9 & 49.48 \\
\hline Tea & 97.57 & 85.97 & 77.91 \\
\hline Paddy & 36.35 & 90.74 & 93.64 \\
\hline Urban & 31.74 & 36.76 & 41.93 \\
\hline
\end{tabular}


Table.3 Percentage area of various LULC classes during 1997 - 2017

\begin{tabular}{|c|c|c|c|}
\hline Year & $\mathbf{1 9 9 7}$ & $\mathbf{2 0 0 7}$ & $\mathbf{2 0 1 7}$ \\
\hline LULC category & Area $(\boldsymbol{\%})$ & Area $(\boldsymbol{\%})$ & Area $(\boldsymbol{\%})$ \\
\hline Waterbody & 2.18 & 3.15 & 2.3 \\
\hline Vegetation & 69.53 & 65.41 & 63.01 \\
\hline Barren land & 12.86 & 11.33 & 14.06 \\
\hline Palm & 2.42 & 3.37 & 3.88 \\
\hline Tea & 7.66 & 6.75 & 6.11 \\
\hline Paddy & 2.85 & 7.12 & 7.35 \\
\hline Urban & 2.49 & 2.88 & 3.29 \\
\hline
\end{tabular}

Table.4 Decadal percentage change in area of various LULC classes

\begin{tabular}{|c|c|c|c|}
\hline & $\mathbf{1 9 9 7 - 2 0 0 7}$ & $\mathbf{2 0 0 7 - 2 0 1 7}$ & $\mathbf{( 1 9 9 7 - 2 0 1 7 )}$ \\
\hline LULC category & Percent change (\%) & Percent change (\%) & Percent change (\%) \\
\hline Waterbody & 0.97 & -0.85 & 0.12 \\
\hline Vegetation & -4.12 & -2.4 & -6.52 \\
\hline Barren land & -1.53 & 2.73 & 1.2 \\
\hline Palm & 0.95 & 0.51 & 1.46 \\
\hline Tea & -0.91 & -0.64 & -1.55 \\
\hline Paddy & 4.27 & 0.23 & 4.5 \\
\hline Urban & 0.39 & 0.41 & 0.8 \\
\hline
\end{tabular}

Table.5 Annual change rate of LULC classes (\%)

\begin{tabular}{|c|c|c|c|}
\hline & \multicolumn{3}{|c|}{ Annual change rate (\%) } \\
\hline LULC category & $\mathbf{1 9 9 7 - 2 0 0 7}$ & $\mathbf{2 0 0 7 - 2 0 1 7}$ & $\mathbf{( 1 9 9 7 - 2 0 1 7 )}$ \\
\hline Water body & 3.64 & -3.13 & 1.04 \\
\hline Vegetation & -0.61 & -0.37 & -1.97 \\
\hline Barren land & -1.27 & 2.16 & 1.78 \\
\hline Palm & 3.29 & 1.43 & 9.43 \\
\hline Tea & -1.27 & -0.98 & -4.5 \\
\hline Paddy & 9.15 & 0.31 & 18.93 \\
\hline Urban & 1.47 & 1.32 & 5.57 \\
\hline
\end{tabular}

Table.6 Land use area change detection matrix for the period 1997-2007 (km²)

\begin{tabular}{|c|c|c|c|c|c|c|c|c|}
\hline Class name & Water body & Vegetation & $\begin{array}{c}\text { Barren } \\
\text { land }\end{array}$ & Palm & Tea & Paddy & Urban & 1997 Total \\
\hline Water body & $\mathbf{2 4 . 3 9}$ & 3.06 & 0.2 & 0.06 & 0.03 & 0.09 & 0.01 & $\mathbf{2 7 . 8 4}$ \\
\hline Vegetation & 10.06 & $\mathbf{6 6 2 . 3 6}$ & 95.24 & 33.45 & 31.93 & 43.76 & 9.4 & $\mathbf{8 8 6 . 2}$ \\
\hline Barren land & 5.08 & 95.73 & $\mathbf{2 3 . 7}$ & 1.08 & 3.09 & 22.74 & 12.49 & $\mathbf{1 6 3 . 9 1}$ \\
\hline Palm & 0.1 & 10.72 & 6.17 & $\mathbf{3 . 0 4}$ & 1.16 & 7.71 & 1.98 & $\mathbf{3 0 . 8 8}$ \\
\hline Tea & 0.07 & 35.16 & 12.79 & 0.71 & $\mathbf{4 5 . 8 5}$ & 2.81 & 0.18 & $\mathbf{9 7 . 5 7}$ \\
\hline Paddy & 0.38 & 10.18 & 2.49 & 0.94 & 1.99 & $\mathbf{8 . 1}$ & 12.27 & $\mathbf{3 6 . 3 5}$ \\
\hline Urban & 0.01 & 16.45 & 3.78 & 3.62 & 1.9 & 5.53 & $\mathbf{3 . 4 5}$ & $\mathbf{3 1 . 7 4}$ \\
\hline 2007 Total & $\mathbf{4 0 . 1}$ & $\mathbf{8 3 3 . 6 8}$ & $\mathbf{1 4 4 . 3 7}$ & $\mathbf{4 2 . 9}$ & $\mathbf{8 5 . 9 7}$ & $\mathbf{9 0 . 7 4}$ & $\mathbf{3 6 . 7 6}$ & $\mathbf{1 2 7 4 . 5 2}$ \\
\hline
\end{tabular}


Table.7 Land use area change detection matrix for the period 2007-2017 (km²)

\begin{tabular}{|l|c|c|c|c|c|c|c|c|}
\hline Class name & $\begin{array}{c}\text { Water } \\
\text { body }\end{array}$ & Vegetation & $\begin{array}{c}\text { Barren } \\
\text { land }\end{array}$ & Palm & Tea & Paddy & Urban & $\begin{array}{l}\mathbf{2 0 0 7} \\
\text { Total }\end{array}$ \\
\hline Water body & $\mathbf{2 7 . 0 4}$ & 6.5 & 6.17 & 0.05 & 0.02 & 0.26 & 0.07 & $\mathbf{4 0 . 1 1}$ \\
\hline Vegetation & 2.18 & $\mathbf{6 5 5 . 0 9}$ & 95.53 & 21.13 & 26.6 & 25.57 & 7.58 & $\mathbf{8 3 3 . 6 8}$ \\
\hline Barren land & 0.02 & 90.61 & $\mathbf{2 5 . 7 9}$ & 3.87 & 10.14 & 8.62 & 5.3 & $\mathbf{1 4 4 . 3 5}$ \\
\hline Palm & 0.01 & 5.16 & 1.49 & $\mathbf{1 5 . 3 5}$ & 1.44 & 12.3 & 8.15 & $\mathbf{4 3 . 9}$ \\
\hline Tea & 0.01 & 22.36 & 15.93 & 0.03 & $\mathbf{3 0 . 3 6}$ & 15.52 & 1.07 & $\mathbf{8 5 . 2 8}$ \\
\hline Paddy & 0.03 & 21.51 & 25.7 & 6.4 & 4.23 & $\mathbf{2 0 . 2 7}$ & 12.36 & $\mathbf{9 0 . 5}$ \\
\hline Urban & 0.03 & 1.86 & 8.55 & 2.64 & 5.12 & 11.11 & $\mathbf{7 . 3 6}$ & $\mathbf{3 6 . 6 7}$ \\
\hline $\mathbf{2 0 1 7}$ Total & $\mathbf{2 9 . 3 2}$ & $\mathbf{8 0 3 . 0 9}$ & $\mathbf{1 7 9 . 1 6}$ & $\mathbf{4 9 . 4 8}$ & $\mathbf{7 7 . 9 1}$ & $\mathbf{9 3 . 6 4}$ & $\mathbf{4 1 . 9 3}$ & $\mathbf{1 2 7 4 . 5 3}$ \\
\hline
\end{tabular}

Table.8 (Gain-Loss) area $\left(\mathrm{km}^{2}\right)$ for each LULC class

\begin{tabular}{|c|c|c|c|c|}
\hline \multirow{2}{*}{$\begin{array}{c}\text { LULC } \\
\text { Classes }\end{array}$} & \multicolumn{2}{|c|}{ Area Gain } & \multicolumn{2}{c|}{ Area Loss } \\
\cline { 2 - 5 } Water body & $1597-2007$ & $\mathbf{2 0 0 7 - 2 0 1 7}$ & $\mathbf{1 9 9 7 - 2 0 0 7}$ & $\mathbf{2 0 0 7 - 2 0 1 7}$ \\
\hline Vegetation & 171.32 & 148 & 223.84 & 178.59 \\
\hline Barren land & 120.67 & 153.37 & 140.21 & 118.56 \\
\hline Palm & 39.86 & 34.13 & 27.84 & 28.55 \\
\hline Tea & 40.12 & 47.55 & 51.72 & 54.92 \\
\hline Paddy & 82.64 & 73.37 & 28.25 & 70.23 \\
\hline Urban & 36.31 & 34.57 & 31.29 & 29.31 \\
\hline
\end{tabular}

Table.9 Net (Gain-Loss) area $\left(\mathrm{km}^{2}\right)$ for each LULC class

\begin{tabular}{|c|c|c|}
\hline LULC & Net gain area $\left(\mathbf{k m}^{\mathbf{2}}\right)$ & Net loss area $\left(\mathbf{k m}^{\mathbf{2}}\right)$ \\
\hline Classes & $\mathbf{1 9 9 7 - 2 0 0 7}$ & $\mathbf{2 0 0 7 - 2 0 1 7}$ \\
\hline Water body & 12.26 & -10.79 \\
\hline Vegetation & -52.52 & -30.59 \\
\hline Barren land & -19.54 & 34.81 \\
\hline Palm & 12.02 & 5.58 \\
\hline Tea & -11.6 & -7.37 \\
\hline Paddy & 54.39 & 3.14 \\
\hline Urban & 5.02 & 5.26 \\
\hline
\end{tabular}


Fig.1 Location map of the study area

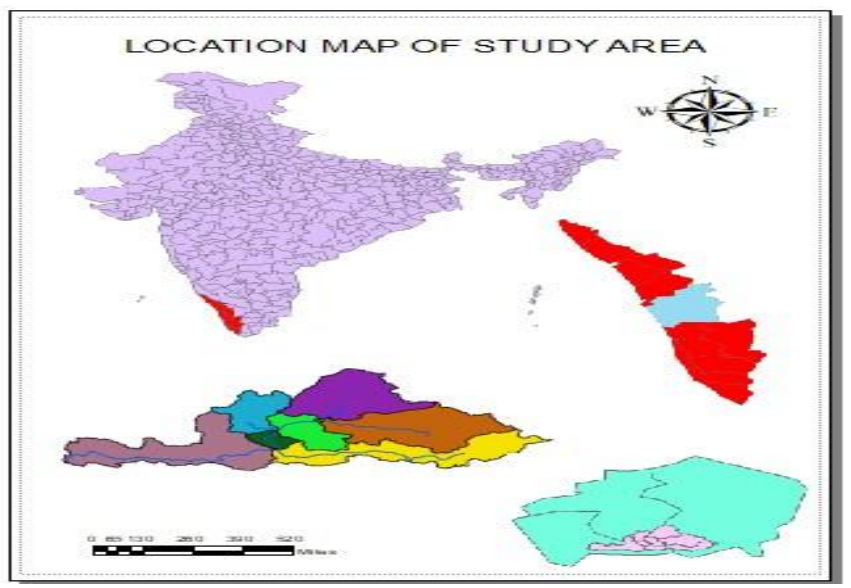

Fig.2 LULC map of Chalakudy basin for the year 1997

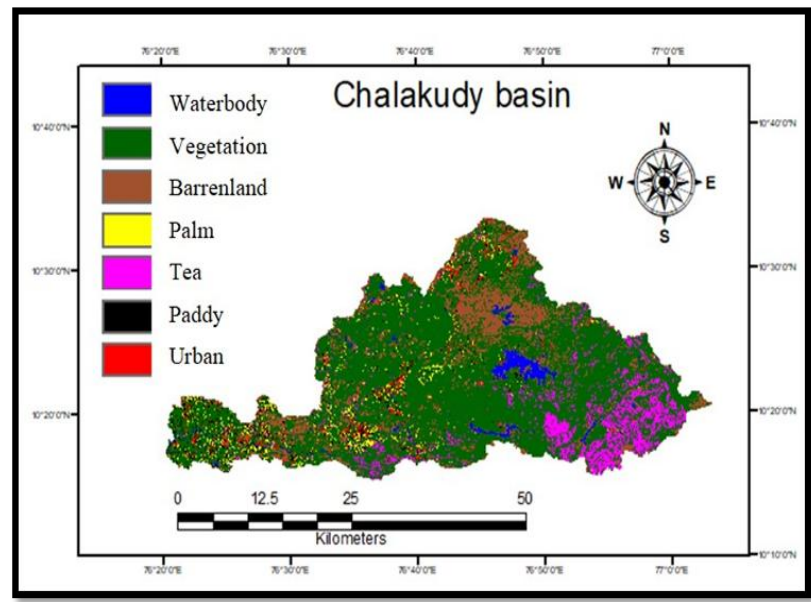

Fig.3 LULC map of Chalakudy basin for the year 2007

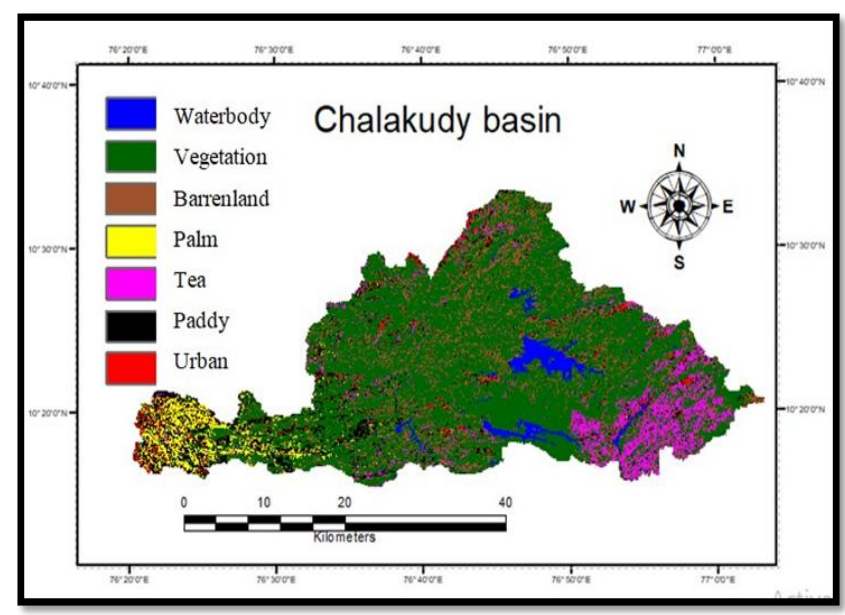


Fig.4: LULC map of Chalakudy basin for the year 2017

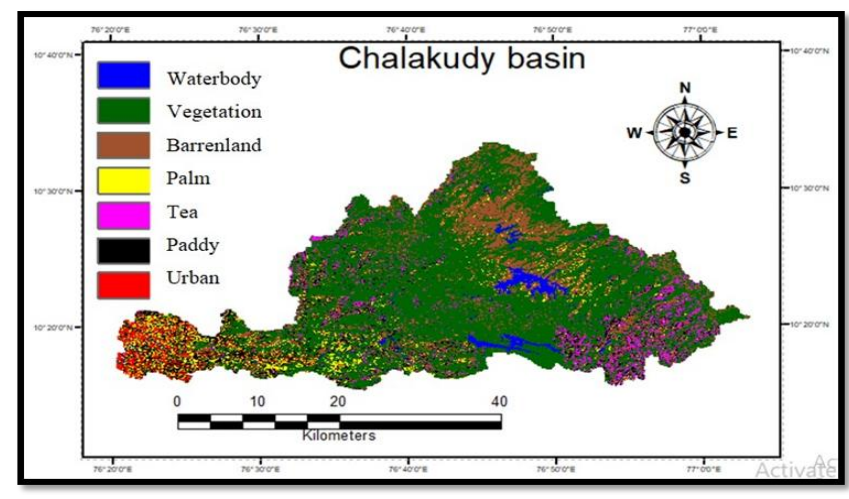

Fig.5 Variation of average rainfall and average flow for the years 1997 to 2007

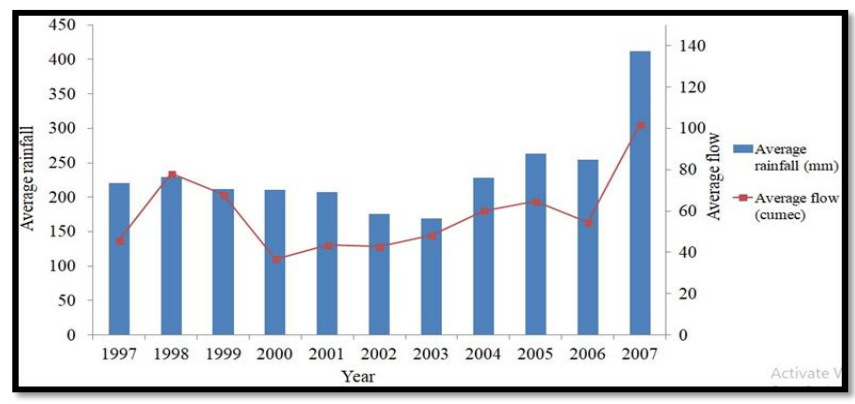

Fig.6 Variation of average rainfall and average flow for the years 2007 to 2017

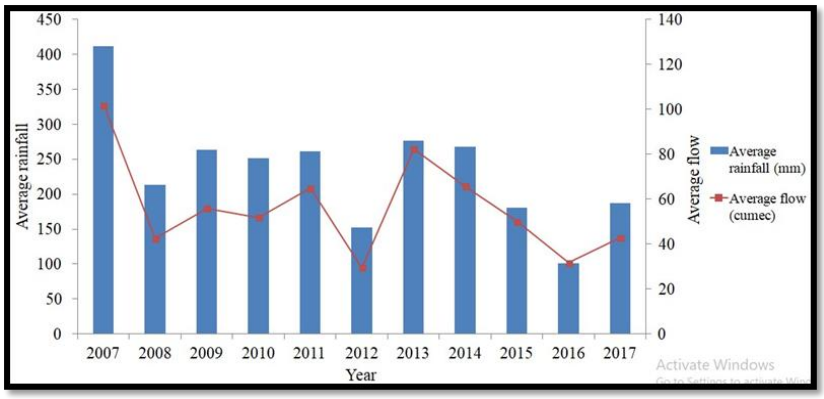

Fig.7 Correlation analysis between avg. rainfall and avg flow (1997 to 2007)

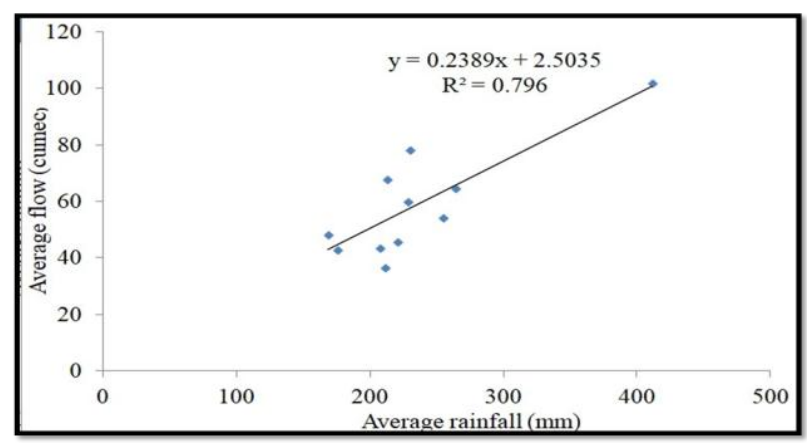


Fig.8 Correlation analysis between avg. rainfall and avg. flow (2007 to 2017)

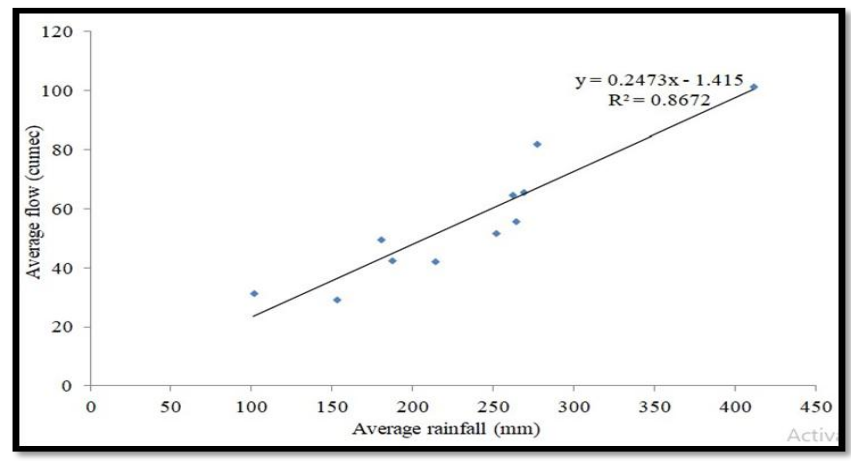

Fig.9 Net gain and losses for different LULC classes

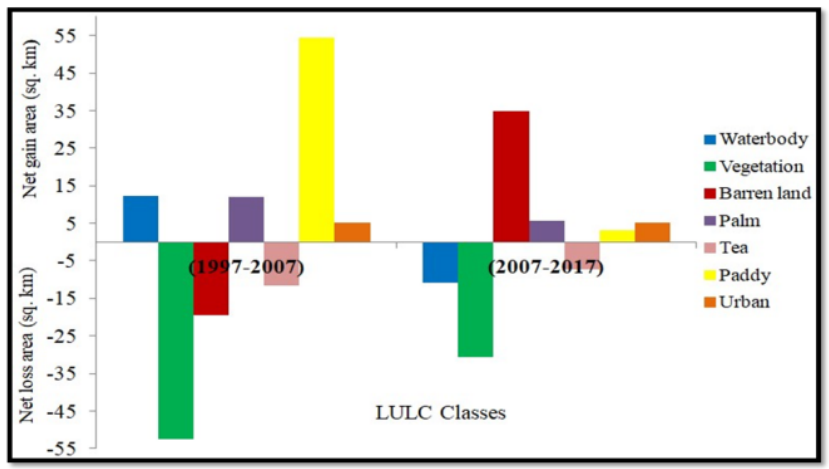

Table 6 shows that $24.39 \mathrm{~km}^{2}$ of water body area remains the same from 1997 to 2007 while a water body area of $27.04 \mathrm{~km}^{2}$ remains constant from 2007 to 2017 (Table 7). Table 6 shows that a water body area of $3.06 \mathrm{~km}^{2}, 0.2$ $\mathrm{km}^{2}, 0.06 \mathrm{~km}^{2}, 0.03 \mathrm{~km}^{2}, 0.09 \mathrm{~km}^{2}$ and 0.01 $\mathrm{km}^{2}$ shifts to vegetation, barren land, palm, tea, paddy and urban respectively from 1997 to 2007. Maximum area to remain constant from 1997 to 2007 is of the vegetation area i.e., $662.36 \mathrm{~km}^{2}$, the same was observed for the year 2007 to 2017 which is $655.09 \mathrm{~km}^{2}$. Table 6 and 7 shows the area shifting mostly towards the urban area is paddy which are $12.27 \mathrm{~km}^{2}$ and $12.36 \mathrm{~km}^{2}$ respectively for 1997 to 2007 and 2007 to 2017.The tea area decreased from $97.57 \mathrm{~km}^{2}$ to $77.91 \mathrm{~km}^{2}$ over the two decades. The paddy, urban and palm area increased from $36.35 \mathrm{~km}^{2}$ to $93.64 \mathrm{~km}^{2}$, $31.74 \mathrm{~km}^{2}$ to $41.93 \mathrm{~km}^{2}$ and $30.88 \mathrm{~km}^{2}$ to $49.48 \mathrm{~km}^{2}$.
From the area gain-loss calculation (Table 8) it was observed that the highest area gain from 1997-2007 was of vegetation with $171.32 \mathrm{~km}^{2}$ and for 2007-2017 it was of barren land with $153.37 \mathrm{~km}^{2}$ while the least gain was of water body for both the decades with an area of $15.71 \mathrm{~km}^{2}$ and $2.28 \mathrm{~km}^{2}$ respectively. The highest area loss was of vegetation for both the decades with an area of $223.84 \mathrm{~km}^{2}$ and $178.59 \mathrm{~km}^{2}$ (Table 8 ) and the least area loss was of water body with an area of $3.45 \mathrm{~km}^{2}$ and $13.07 \mathrm{~km}^{2}$ respectively.

Table 9 and fig 9 shows that the highest loss from 1997-2007 was of vegetation (-52.52 $\mathrm{km}^{2}$ ) and the highest gain was of Paddy $\left(54.39 \mathrm{~km}^{2}\right)$. In between 2007-2017 the highest loss was noticed for vegetation ($30.59 \mathrm{~km}^{2}$ ) while the highest gain was for barren land $\left(34.81 \mathrm{~km}^{2}\right)$. 
The present study was conducted in the Chalakudy river basin of Kerala to analyze the effect of land use land cover changes on the runoff processes of this basin using Arc GIS and ERDAS Imagine. From the analysis of different LULC maps it can be concluded that the runoff is influenced not only because of LULC changes but also by an increase or decrease in the amount of rainfall the watershed receives. Another reason behind the runoff experienced by the watershed is a consistent decrease in the amount of vegetation area and an increase in barren land over the past two decades which created a negative impact on the infiltration capacity of the soil as well. Area coverage of $27.84 \mathrm{~km}^{2}, 40.10 \mathrm{~km}^{2}$ and 29.32 $\mathrm{km}^{2}$ for urban area class was noticed and the highest area coverage was for the vegetation class which was $886.21 \mathrm{~km}^{2}, 833.68 \mathrm{~km}^{2}$ and $803.09 \mathrm{~km}^{2}$ respectively for the years 1997 , 2007 and 2017.The percentage area covered by urban area class varied from $2.49 \%$ to $2.88 \%$ and $3.29 \%$ and the highest area coverage was found for the vegetation class which was $69.53 \%, 65.41 \%$ and $63.01 \%$ respectively for the years 1997, 2007 and 2017. The annual rate change for 1997-2007 was found to be the highest for paddy with $9.15 \%$ and least for vegetation with $-0.61 \%$ while from 2007-2017 the highest decline of annual rate change was for the water body $(-3.13 \%)$ and least for paddy $(0.31 \%)$. An $\mathrm{R}^{2}$ value of 0.79 was obtained for the linear regression analysis plotted between the average rainfall and average flow for the years 1997-2007 while an $R^{2}$ value of 0.86 was obtained for the years 2007-2017. From the $\mathrm{R}^{2}$ value obtained, it is understood that the flow of the basin is not only dependent on the rainfall but is also influenced by other factors like the changes in the LULC over a stretch of time.

As the Chalakudy basin have been portrayed by urbanization along the stream in the course of the most recent decade and may keep on encountering broad scene changes later on, the potential for expanded release and urban flooding is plausible. The data obtained from this study will be valuable in anticipating crisis like urban floods, and to plan catastrophe mitigation measures. This sort of investigation can bolster significant associations for future land use and flood studies which will help in executing designs so as to ensure and decrease the effect on life. Such studies will also provide an advantage to the neighbourhood individuals in and around the Chalakudy basin and the government as well to come up with some effective steps to prevent further degradation of basin in the near future.

The base of any runoff estimation in a given basin is to incorporate the processes of the hydrological parameters and the relationship between precipitation with geography, existing land use and soil type. It is concluded that the runoff processes of the Chalakudy basin changes with the land use land cover, soil condition and precipitation amount. Studies likewise reasoned that the transformation of agriculture land to rural land expands the runoff amount. From the above study it may very well be presumed that as the land use/land cover over a stream basin changes, the runoff of the basin is likewise influenced or changed. The pattern of LULC change analysis and its influence on runoff at Chalakudy basin shows that the peak flow has increased over the time frame. The primary explanation behind this land use and land over change might be the expansion in population size and per-capita prerequisite of common resources. The significant transformation happened in agriculture land to developed land class because of various anthropogenic reasons. The basin was exposed to urbanization and this was basically to the detriment of agricultural zone. The extreme variabilities in the land use pattern of Chalakudy stream basin uncovered negative changes influencing the basin nature and exasperating the flood and dry season circumstance of this basin. The increment in developed zone, quick progress of rich land to badlands, increasing deforestation, changing agrarian harvest power and so forth requires an immediate requirement for a timely intervention to protect the basin. The main solution to tackle the advancement in urban development is an urgent complete arrangement of policies with 
persistent management. This investigation underpins that preparation of LULC map by incorporating remote sensing and GIS is exceptionally valuable to distinguish the land use land cover changes and finally examine its impact on runoff occurrence. Thus, Satellite remote detecting was helpful in examining LULC changes recognizing the progress of Chalakudy basin within the study period.

\section{References}

Batar, A. K., Watanabe, T., and Kumar, A. (2017). Assessment of Land use/Land cover change and forest fragmentation in the Garhwal Himalayan region of India. Environ. 4:34.

Esa, E., Assen, M., and Legass, A. (2018). Implications of land use/cover dynamics on soil erosion potential of agricultural watershed, north western highlands of Ethiopia. Environ. Syst. Res. 7:21

Franci, F., Bitelli, G., Mandanici, E., Hadjimitsis, D., and Agapiou, A. (2016). Satellite remote sensing and GIS-based multi-criteria analysis for flood hazard mapping. Nat Hazards. 83(S1):31-51.

Lydia, A., Selvam, S., Sivasubramanian, P., Murugan, D. (2018). Evaluation of land use/land cover changes in the Coimbatore Corporation of Tamil Nadu using remote sensing and GIS. J. of Emerging Technol. and Innovative Res. 5(12).

Mayaja, N. A., and Srinivasa, C. V. (2017). Land use and land cover changes and their impacts in Pampa river basin in Kerala: A remote sensing based analysis. $J$. of Geomatics. 11(1).

Mousavi, M. S., Roostaei, S., and Rostamzadeh, H. (2019). Estimation of flood land use/land cover mapping by regional modelling of flood hazard at sub-basin level case study: Marand basin. Geomatics, nat. hazards and risk. 10: (1155-1175).

Munthali, M., Botai, O. J., and Davis, N. (2019). Multi-temporal analysis of land use and land cover change detection for Dedza district of Malawi using geospatial techniques. Int. J. of Appl. Eng. Res. 14(5): 1151-1162.

Prakash, C. R., Sreedevi, B. (2017). Land-use land-cover change and its impact on surface runoff using Remote Sensing and GIS. Int. J. of Advanced Remote Sensing and GIS. 6 (1): 2103-2113.

Puyravaud, J. P., (2003).Standardizing the calculation of the annual rate of deforestation. For. Ecol. and Manag. 177:593-596.

Syed, M. Z. Y., Ahmad A. (2018). Quantification of impact of changes in land use-land cover on hydrology in the upper Indus basin, Pakistan. The Egyptian J. Of Remote Sensing and space sciences. 21:255-263.

Teferi, E., Bewket, W., Uhlenbrook, S., and Wenninger, J. (2013). Understanding recent land use and land cover dynamics in the source region of the Upper Blue Nile, Ethiopia: Spatially explicit statistical modeling of systematic transitions. Agric. Ecosyst. Environ. 165: 98-117.

Vojtek, M., and Vojtekova, J. (2016). Flood hazard and flood risk assessment at the local spatial scale: a case study. Geomat. Nat. Hazards and Risk. 7(6):1973-1992.

Zamfir, A., and Simulescu, D. (2011). Automatic delineation of a watershed using a DEM. case study - the Olteţ watershed. Sci. Ann. of Stefan cel Mare University of Suceava Geogr. Ser. 20(1).

\section{How to cite this article:}

Nchumbeni M. Odyuo and Rema, K. P. 2020. Impact of Land Use Land Cover Changes on Runoff Processes of Chalakudy Basin. Int.J.Curr.Microbiol.App.Sci. 9(11): 3731-3742. doi: https://doi.org/10.20546/ijcmas.2020.911.447 